\title{
Evaluating Impact of Micro and Toxic Elements on Soil and Natural and Cultivated Plants in Rabigh Industrial City
}

\author{
Ahmed Abdullah Al-Qarne, Samir G. M. Al-Solaimani, Ahmed. A. Bakhashwain \\ Department of Arid Land Agriculture, \\ Faculty of Meteorology, Environment \& Arid Land Agriculture, \\ King Abdulaziz University P.O. Box 80208, Jeddah: 21589, Saudi Arabia
}

\begin{abstract}
The present work was carried out to investigate the impact of micro and toxic elements in soil and water quality and growth of natural and some cultivated plants. Soil, water and plant samples were collected from three sites, Kiliya village, Rabigh city and Masturah village in Rabigh Governorate. All analysis were carried out in the lab of soil science, Department of Arid Land Agriculture, King Abdulaziz University. The results revealed significant differences between the three sites concerning accumulation of micro and toxic elements in soil, water and plants. Significant differences were observed between analyzed soil, water and plant samples in $\mathrm{Fe}$, $\mathrm{Zn}, \mathrm{Mn}, \mathrm{Cd}, \mathrm{Ni}, \mathrm{Ph}, \mathrm{Cr}$ contents. The concentrations of $\mathrm{Fe}, \mathrm{Zn}$, $\mathrm{Mn}, \mathrm{Cd}, \mathrm{Ni}, \mathrm{Ph}, \mathrm{Cr}$ in plants, and soil samples were below the standards WHO/ FAO 2007 for plant and EU.(2002) for soil. The concentrations of $\mathrm{Fe}, \mathrm{Zn}, \mathrm{Mn}, \mathrm{Cd}, \mathrm{Ni}, \mathrm{Ph}, \mathrm{Cr}$ in well water below the standards of (MEWA 2005) and FAO (1985), except water electrical conductivity (EC) and chromium (Cr) contents. The results illustrated that natural plants were characterized by higher concentrations of micro and toxic elements in Rabigh city experimental site than Musturah site and Keliya site. The experimental site of Kiliya showed the highest content of micro elements $(\mathrm{Fe}, \mathrm{Zn}, \mathrm{Mn}, \mathrm{Cu}, \mathrm{Cd}, \mathrm{Ni}, \mathrm{Pb}$ and $\mathrm{Cr}$ ) with averages $(271,2,1.47), 10,67,1,17,0.023,1,55$, 4,92, $2.09 \mathrm{mg} / \mathrm{L}$ ) as compared to experimental sites of Rabigh city and Msturah. Regarding water and soil $\mathrm{Ph}$ the results showed no significant differences between the three experimental sites. The electric conductivity (EC) of water and soil was higher in Masturah village site as compared to experimental sites of Rabigh city and Kiliya village. The highest concentrations of micro and toxic elements were observed for water, soil and plant samples of Rabigh city as compared to Mastura village and the village of Kiliya. The pollution levels at Rabigh city were lower than local and international standards.
\end{abstract}

Key words: Rabigh governate, micro and toxic elements, pollution, heavey metals, natural plants.

\section{INTRODUCTION}

Pollution affects the atmosphere, vegetation and soil, which is a serious problem in many regions of the world. Pollution is particularly problematic in the vicinity of sources of pollution. The effect of pollution can be physical on the plant through the deposition of particles on the surface of leaves with a detrimental effect on the growth of plants and changes in the activities of stomata (opening and closing mechanisms). The effect can be chemically so by nutrient uptake of the soil and modifications in the ways of recycling the nutrients needed for the plant and their availability for absorption by 2

plants. Industrial cities are normally subjected to pollution as regards its water sources, its soil and its plants. This is because different types of factories and different types of industrial activities represent the main sources of pollution with heavy and toxic metals. On the other hand, many studies have studied the physical effect and chemical effect of pollution on plants, particularly with regard to the accumulation of plant elements (Santelmann and Gorham 1988) and the effect of pollution on the physiological activities of plants (Roser et al., 1992; Hong-Xia et al., 2006) ; Mandre et al. (2008). Most of these studies have shown a decrease in photosynthesis, changes in pigments and plant growth due to exposure of plants to pollution (Brandt and Rhoades 1973; Arianoutsou et al., 1993; Mandre and Tuulmets 1997; Lepedus et al., 2003). For example, "cement dust" in particular, may release calcium hydroxide, which can dissolve or decompose leaf proteins (Czaja 1960, 1961, 1962; Guderian 1986). Hemlata (1991) observed that the activities of three enzymes in plants increased with the increased concentration of cement dust. Soil dust contamination may also lead to a significant reduction in soil microbial biomass (Semhi et al 2009). The composition and concentration of toxic and microbial elements in the plant is directly related to the surrounding environmental conditions of temperature, precipitation and the like,and as the season is hot, weathering and rock decomposition (Nagajyoti et al., 2010, . Alghabari et al., 2015). In the summer season, dust is high in the wind, and this dust is saturated with heavy metals and dust from desert areas contains high levels of iron and fewer manganese, zinc, chromium, nickel and lead (Ross, 1994). A field study was conducted near Jeddah Industrial Zone to assess the potential for accumulation of air pollutants in Ziziphus trees, and the concentration of iron, copper, zinc, and manganese increased by 89, 37, 60 and $93 \%$ respectively, compared to trees away from this site (ElNakhlawi, et al. 2014). The present work focused on evaluating impacts of heavy and toxic elements on soil, water and plants (naturally grown and cultivated plants) at three different sites of Rabigh governorate. . 


\section{MATERIALS AND METHODS}

Experimental sites:

In order to evaluate the pollution level with micro and toxic elements in soil, water and plants (naturally grown and cultivated plants), three different sites of the industrial city at Rabigh Governorate called : Kiliya villages, Rabigh city and Masturah vallage were selected (Fig 1). The longitudes and maps of the three sites were presents in Table (1).

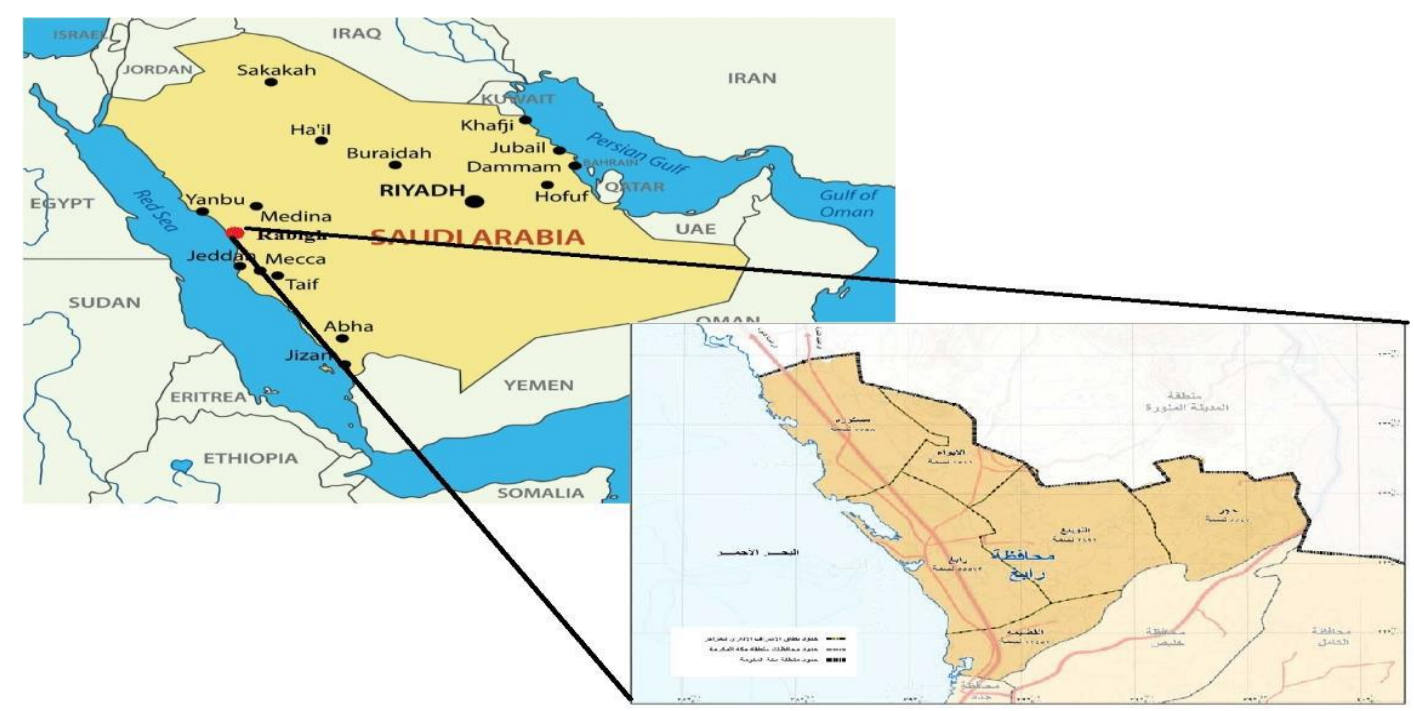

FIG (1): RABIGH INDUSTRIAL CITY IN SAUDI ARABIA

TABLE 1: LONGITUTE AND MAP OF THE THREE EXPERIMENTAL SITES UNDER INVESTIGATION AT RABIGH GOVERNATE : A) KILIYA VILLAGES, B) RABIGH CITY AND C) MASTURAH CITY.

\begin{tabular}{|c|c|c|c|}
\hline \multirow{2}{*}{ site } & & & \\
\hline & Longitudinal line & Width line & Map tie \\
\hline A & E $39^{\circ} 15^{\prime} 53.5^{\prime \prime}$ & N 22 $30^{\prime} 54.9^{\prime \prime}$ & $\begin{array}{c}\text { https://www.google.com.sa/maps/place/22\%C2\%B030'54.9\%22 } \\
\mathrm{N}+39 \% \mathrm{C} 2 \% \text { B015'53.5\%22E/@ } 22.5151903,39.2624673,851 \mathrm{~m} / \mathrm{d} \\
\text { ata=!3m1!1e3!4m5!3m4!1s0x0:0x0!8m2!3d22.51525!4d39.2648 } \\
611\end{array}$ \\
\hline B & E $39^{\circ} 10^{\prime} 38.5^{\prime \prime}$ & N $22^{\circ} 38^{\prime} 24.5^{\prime \prime}$ & 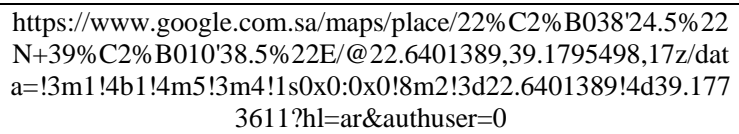 \\
\hline $\mathrm{C}$ & E $38^{\circ} 54^{\prime} 12.2^{\prime \prime}$ & $\mathrm{N} 23^{\circ} 3^{\prime} 6.3^{\prime \prime}$ & $\begin{array}{l}\text { https://www.google.com.sa/maps/place/23\%C2\%B003'06.3\%22 } \\
\text { N+38\%C2\%B054'12.2\%22E/@ 23.0517549,38.9055776,17z/dat } \\
\text { a=!3m1!4b1!4m5!3m4!1s0x0:0x0!8m2!3d23.05175!4d38.90338 }\end{array}$ \\
\hline
\end{tabular}

\section{Sample collection:}

Plant Samples

Leaf samples were collected from the following naturally grown and cultivated plant species: samar (Acacia tortilis), Apple of Sodom (Calatropis procera), Senegal senna (Senna italic), Leptadenia pyrotechnica, Pearl millet (Pennisetum glaucum), Blue Panic grass (Panicum antidotale), Bermuda Grass )Cynodon dactylon), Pennisetum purpureum and Rhodes grass (Chloris gayana (kunth). The plant samples were put in paper bags, taken to the laboratory and put in oven at $70{ }^{\circ} \mathrm{C}$ for 24 hours, then grinded into powder and put in plastic bags and stored at $4{ }^{\circ} \mathrm{C}$ for analysis.
Soil Samples soil samples were taken at 3 depths, soil surfaces, $15 \mathrm{~cm}$ and $30 \mathrm{~cm}$ from soil surface. Samples were put in paper badges and stored on room temperature until use.

Analysis of Soil samples:

Soil analysis was conducted in the lab of soil and water sciences, Department of Arid Land Agriculture, King Abdulaziz University. Soil $\mathrm{pH}$ and electric conductivity (EC) were estimated using a 1: $1(\mathrm{~W}: \mathrm{V})$ soil: water. The concentrations of Iron (Fe), Zinc ( $\mathrm{Zn})$, Manganese (Mn), Copper $(\mathrm{Cu})$, Lead $(\mathrm{Pb})$, Chromium $(\mathrm{Cr})$, cadmium $(\mathrm{Cd})$ and nickel $(\mathrm{Ni})$ were determined using an atomic absorption 
device. These elements were estimated after digestion with pyrochloric acid and nitric (Shelton and Harper, 1941). These elements were estimated using the Atomic Absorption Spectro Photometer model 5000 perkin Elmer.

Analysis of plant samples:

Samples of naturally grown and cultivated plants were used. The concentrations of Iron (Fe), Zinc ( $\mathrm{Zn})$, Manganese $(\mathrm{Mn})$, Copper $(\mathrm{Cu})$, Lead $(\mathrm{Pb})$, Chromium $(\mathrm{Cr})$, cadmium (Cd) and nickel (Ni) were determined using an atomic absorption device. These elements were estimated after digestion with pyrochloric acid and nitric (Shelton and Harper, 1941). These elements were estimated using the Atomic Absorption Spectro Photometer model 5000 perkin Elmer.

Analysis of Water Samples :

Various chemical analyzes were carried out according to the standard methods used by the American Public Health Organization for Water Analysis (APHA, 1998). The conductivity meter was used to measure the conductivity of Md / cm and the device was calibrated using a standard solution of potassium chloride $(\mathrm{KCl})$. The $\mathrm{pH}$ was measured by a glass electrode $\mathrm{pH}$ meter and the device was calibrated using Buffer Solutions. The concentrations of Iron (Fe), Zinc $(\mathrm{Zn})$, Manganese $(\mathrm{Mn})$, Copper $(\mathrm{Cu})$, Lead $(\mathrm{Pb})$, Chromium $(\mathrm{Cr})$, cadmium $(\mathrm{Cd})$ and nickel $(\mathrm{Ni})$ were determined using an atomic absorption device. These elements were estimated after digestion with pyrochloric acid and nitric (Shelton and Harper, 1941). These elements were estimated using the Atomic Absorption Spectro Photometer model 5000 perkin Elmer.

Statistical Analysis:

Statistical analyzes of the results measured in the study were carried out by calculating the analysis of variance for each of the measured traits in the soil, plant and water. The statistical comparisons of the mean of the mean parameters were then carried out by the LSD test at a significant level of 0.05 according to El- Nakhlawy (2010) Statistical Analysis SAS(SAS, 2010).

\section{RESULTS:}

Effect of Experimental site on electric conductivity (EC) and acidity $(\mathrm{pH})$ of irrigation water and soil:

The results showed significant differences between the three experimental sites as regards EC of irrigation water and soil samples, while the results were not significant wit regard soil $\mathrm{pH}$ table (1). The experimental site 'Masturah'revealed the highest EC values for soil and water samples $(3.61 \mathrm{ds} / \mathrm{m}$ for water and $35.38 \mathrm{ds} / \mathrm{m}$ for soil ), followed by water and soil samples of the experimental site Rabigh city' with $3.32 \mathrm{ds} / \mathrm{m}$ for water and $1.64 \mathrm{ds} / \mathrm{m}$ for soil. The least EC values of water and soil samples were 2.83 and $0.95 \mathrm{ds} / \mathrm{m}$ and observed for) Kiliya villages site (Table 2).

TABLE (1): ANALYSIS OF VARIANCE OF EC AND PH IN WELL WATER AND SOIL OF SITES

\begin{tabular}{|c|c|c|c|c|c|}
\hline & & \multicolumn{2}{|c|}{ Well water } & \multicolumn{2}{|c|}{ soil } \\
\hline Source of Variation. & df & $\mathbf{E c}(\mathbf{d s} / \mathbf{m})$ & $\mathbf{p H}$ & $\mathbf{E c}(\mathbf{d s} / \mathbf{m})$ & PH \\
& & & & & 0.44 \\
\hline Rep & 2 & 0.027 & 0.040 & 0.072 \\
\hline Loc & 2 & $0.455^{* *}$ & $0.123 \mathrm{Ns}$ & $1162.37 * *$ & $0.081 \mathrm{Ns}$ \\
\hline Error & 4 & 0.005 & 0.091 & 0.188 & 0.027 \\
\hline
\end{tabular}

Showing a significant effect at $0.05 *$ Showing a significant effect at $0.01 * *$

TABLE (2): AVERAGE VALUES OF PH AND EC IN IRRIGATION WELL WATER AND SOIL OF STUDIED SITES

\begin{tabular}{|c|c|c|c|c|c|c|c|c|}
\hline \multirow{2}{*}{ Sites } & \multicolumn{4}{|c|}{ Well water } & \multicolumn{4}{|c|}{ soil } \\
\hline & & & & & $\mathrm{pH}$ & & $\mathrm{EC}$ & \\
\hline Kiliya villages & 7.56 & $\mathrm{a}$ & 2.8 & c & 7.23 & $\mathrm{a}$ & 0.95 & $\mathrm{~b}$ \\
\hline Rabigh & 7.15 & $\mathrm{a}$ & 3.3 & $\mathrm{~b}$ & 7.15 & $\mathrm{a}$ & 1.64 & $\mathrm{~b}$ \\
\hline Masturah & 7.36 & $\mathrm{a}$ & 3.6 & a & 6.91 & $\mathrm{a}$ & 35.38 & $\mathrm{a}$ \\
\hline
\end{tabular}

The averages followed by the same letters did not differ significantly from each other according to the Lsd test at a significant level of $0.05 *$ 
Salinity of well water:

Well water in these three sites are used for irrigation. The average concentration of total soluble salts in well water in the three different sites is $1800,2200,2400 \mathrm{mg} / \mathrm{L}$ in the three sites respectively. These salinity values are higher than the criteria set by the Food and Agriculture Organization (FAO, 1985), but below the standard set by Ministry of Environment and Water and Agriculture of Saudi Arabia (MEWA, 2005),(table 3).

\section{TABLE (3): THE AVERAGE CONCENTRATION OF TOTAL SOLUBLE SALTS IN WELL WATER IN THE THREE DIFFERENT SITES}

\begin{tabular}{|c|c|c|c|c|c|}
\hline \multirow{2}{*}{ Parameter } & \multicolumn{3}{|c|}{ Sites } & \multirow{2}{*}{ MEWE) } & \multirow{2}{*}{ FAO } \\
\cline { 2 - 5 } & Kiliya villages & Rabigh & Masturah & & 2000 \\
\hline $\begin{array}{c}\text { Total dissolved } \\
\text { salts(TDS) }\end{array}$ & $1808-1826$ & $2054-2201$ & $2208-2412$ & 2500 & 2000 \\
\hline
\end{tabular}

\section{Effect of experimental sites on natural and cultivated plants} contents of micro and toxic elements

The results showed that there are significant differences $(\mathrm{P}$ $\leq 0.01$ ) between the three different sites in Rabigh governorate with respect to the content micro and toxic elements $(\mathrm{Fe}, \mathrm{Zn}, \mathrm{Mn}, \mathrm{Cu}, \mathrm{Pb}, \mathrm{Cr}$ ) on samples of natural and cultivated plants. As presented in Table (4) there were no significant differences between the sites with respect to the contents of cadmium and nickel $(\mathrm{Cd}, \mathrm{Ni})$. These results revealed that the highest contents of micro and toxic elements were observed for plant samples of the experimental site Kiliya villages. For instance, iron $(\mathrm{Fe}=$ $21.61 \mathrm{mg} / \mathrm{l})$ and the manganese $(\mathrm{Mn}=0.856 \mathrm{mg} / \mathrm{l})$, Chromium $(\mathrm{Cr}=0.190 \mathrm{mg} / \mathrm{l})$ and zinc $(\mathrm{Zn}=0.481)$. Contrary, the least contents of micro and toxic elements were observed for plant samples of the experimental site 'Masturah city' except $\mathrm{Pb}$ (0.336 mg / 1) (Table 5). Table (6) shows micro and toxic elements contents in some naturally growing plants in the three locations in Rabigh Governorate (Kiliya, Rabigh and Masturah). The results showed tha the highest concentrations of iron $(\mathrm{Fe})$ were found in the millet plant at the third site (Masturah), between 19.55 - $25.8 \mathrm{mg} /$ $\mathrm{L}$, and in the plant of Chloris gayana (kunth) in Rabigh, (74 - $17.55 \mathrm{mg} / \mathrm{L}$ ), and in Blue panic (Panicum antidotalea) plant in Rabigh (8.1-8.28 mg / L), and in Senna italica plant in Kiliya villages $(8,15-8.76 \mathrm{mg} / \mathrm{L})$. The highest content of zinc (Zn) was also in millet in Masturah site (0.978 - 1.09 $\mathrm{mg} / \mathrm{L}$ ),

then in the Panicum antidotale in Rabigh $(0.84-0.93 \mathrm{mg} / \mathrm{L})$, and the Chloris gayana (kunth) plant in Rabigh (0.74 - 0.80 $\mathrm{Mg} / \mathrm{L}$ ). The highest content of manganese (Mn) was found in Chloris gayana (kunth) in Rabigh (2,38 - $2.48 \mathrm{mg} / \mathrm{L}$ ), and Panicum antidotale in Rabigh $(1.45-1.62 \mathrm{mg} / \mathrm{L}$ ), and in Pennnisetum purpureum (elephant feed plant), $99 \mathrm{mg} / \mathrm{l}$ ) in Masturah. The highest concentration of copper $(\mathrm{Cu})$ was found in millet plant $(0,281-0.338 \mathrm{mg} / \mathrm{L})$ at Masturah and in the Chloris gayana (kunth) plant in Rabigh (0,281-0.287 $\mathrm{mg} / \mathrm{L}$ ). The highest content of cadmium (Cd) was found in millet (0.0143-0015 mg / 1) at Masturah site and in Panicum antidotale in Rabigh (0.014 - $0.015 \mathrm{mg} / \mathrm{L})$. The highest Ni content was found in the Chloris gayana (kunth) plant in Rabigh (0.067-0,076 mg /L. The highest content of the lead element $(\mathrm{Pb})$ was also found in the Chloris gayana (kunth) plant in Rabigh (0.382 - $0.386 \mathrm{mg} / \mathrm{L})$ and the Panicum antidotale plant in Rabigh $(0.371-0.399 \mathrm{mg} / \mathrm{L})$. The highest content of chromium (Cr) was found in millet and Cynodon dactylon plant in Masturah, $(0.112,313 \mathrm{mg} / \mathrm{L})$ and $(0,214-0.267 \mathrm{mg} / \mathrm{L})$ respectively, showing that the plants growing at Rabigh have the highest rates of micro and toxic elements, followed by naturally growing plants at Mastura city and the least contents of the of these elements are in Kiliya villages site

TABLE (4): - ANALYSIS OF VARIANCE OF THE MICRO AND TOXIC ELEMENTS IN A. TORTILIS PLANT UNDER THE INFLUENCE OF THE SAMPLING SITE OF THE GOVERNORATE

\begin{tabular}{|c|c|c|c|c|c|c|c|c|c|}
\hline \multirow{2}{*}{$\begin{array}{l}\text { Source of } \\
\text { Variation. }\end{array}$} & \multirow[t]{2}{*}{ df } & \multicolumn{4}{|c|}{ Micro-elements (mg/l) } & \multicolumn{4}{|c|}{ Toxic elements (mg/l) } \\
\hline & & $\mathrm{Fe}$ & $\mathrm{Zn}$ & $\mathrm{Mn}$ & $\mathrm{Cu}$ & $\mathrm{Cd}$ & $\mathrm{Ni}$ & $\mathrm{Pb}$ & $\mathrm{Cr}$ \\
\hline rep & 2 & 5.27 & 0.0002 & 0.0032 & 0.00002 & $3.44 \mathrm{e}-8$ & 0.0016 & 0.00008 & 0.00007 \\
\hline Loc & 2 & $\begin{array}{r}17 * * \\
2.34\end{array}$ & $\begin{array}{rl}0.0 & * * \\
& \\
& \end{array} 26$ & $0.1299 * *$ & $0.00352 *$ & $3.66 \mathrm{e}-8 \mathrm{NS}$ & $0.0027 \mathrm{NS}$ & $0.01634 \quad * *$ & $0.00308 \quad * *$ \\
\hline error & 4 & 4.24 & 0.001 & 0.0041 & 0.0004 & $8.11 \mathrm{e}-8$ & 0.0015 & 0.00015 & 0.00008 \\
\hline
\end{tabular}

Showing a significant effect at $0.05 *$ Showing a significant effect at $0.01 * *$

Not significant for a significant level of 0.05 NS 
TABLE (5): AVERAGE CONCENTRATIONS OF MICRO AND TOXIC ELEMENTS IN PLANT SAMPLES AS COMPARED TO THE TOXICITY STANDARDS OF THE FAO AND WHO ORGANIZATIONS WHO/ FAO 2007

\begin{tabular}{|c|c|c|c|c|c|c|c|c|c|}
\hline Treat. & \multicolumn{4}{|c|}{ Micro-elements (mg/l) } & \multicolumn{5}{|c|}{ Toxic elements (mg/l) } \\
\hline B & $7.27 \mathrm{~b}$ & $0.488 \mathrm{a}$ & $0.448 \mathrm{~b}$ & $0.243 \mathrm{a}$ & $0.0128 \mathrm{a}$ & $0.067 \mathrm{a}$ & $0.219 \mathrm{~b}$ & 0.128 & $\mathrm{~b}$ \\
\hline $\mathrm{C}$ & $10.19 \mathrm{~b}$ & $0.255 \mathrm{~b}$ & $0.579 \quad \mathrm{~b}$ & $0.178 \mathrm{~b}$ & $0.0129 \mathrm{a}$ & $0.035 \mathrm{a}$ & $0.336 \quad \mathrm{a}$ & 0.144 & $\mathrm{~b}$ \\
\hline $\begin{array}{c}\text { Cytotox } \\
\text { range } \\
(\mathrm{mg} / \mathrm{kg})\end{array}$ & - & 50 & - & 40 & 0.2 & 1.5 & 5 & & 5 \\
\hline
\end{tabular}

The averages followed by the same letters did not differ significantly from each other according to the Lsd test at a significant level of $0.05 *$

TABLE (6): CONCENTRATIONS OF MICRO AND TOXIC ELEMENTS (MG / KG) IN THE GROWING NATURAL PLANTS OF RABIGH INDUSTRIAL GOVERNORATE COMPARED WITH STANDARDS OF TOXICITY IN THE FAO AND WHO ORGANIZATIONS WHO/ FAO 2007

\begin{tabular}{|c|c|c|c|c|c|c|c|c|c|c|}
\hline \multirow[t]{2}{*}{ Elements } & \multirow{2}{*}{$\begin{array}{c}\text { Senna italica } \\
\mathbf{A}\end{array}$} & $\begin{array}{l}\text { Chloris } \\
\text { gayana }\end{array}$ & $\begin{array}{c}\text { Panicum } \\
\text { antidolate }\end{array}$ & \multicolumn{2}{|c|}{ Pennisetum purpureum } & $\begin{array}{l}\text { Cynodon } \\
\text { dactylon }\end{array}$ & $\begin{array}{l}\text { Chloris } \\
\text { gayana }\end{array}$ & $\begin{array}{l}\text { Leptadenia } \\
\text { pyrotehnica }\end{array}$ & Pearl millet & $\begin{array}{c}\text { Cytotoxi } \\
\text { range } \\
\text { (mg/kg) }\end{array}$ \\
\hline & & \multicolumn{2}{|l|}{ B } & \multicolumn{6}{|c|}{$\mathrm{C}$} & \\
\hline $\mathrm{Fe}(\mathrm{mg} / \mathrm{l})$ & $8.15-8.76$ & $17.55-14.75$ & $8.1-8.28$ & $5.02-5.81$ & $5.62-5.75$ & $25.8-19.55$ & $2.93-3.13$ & $4.42-6.51$ & $4.003-6.2$ & - \\
\hline $\mathrm{Zn}(\mathrm{mg} / \mathrm{l})$ & $0.171-0.191$ & $0.74-0.80$ & $0.84-0.93$ & $0.336-0.418$ & $0.40-0.41$ & $0.46-0.52$ & $0.53-0.56$ & $0.34-0.49$ & $0.978-1.09$ & 50 \\
\hline $\mathrm{Mn}(\mathrm{mg} / \mathrm{l})$ & $0.432-0.475$ & $2.38-2.48$ & $1.45-1.62$ & $0.593-0.767$ & $0.97-0.99$ & $0.89-0.988$ & $0.50-0.52$ & $0.51-0.59$ & $0.736-0.813$ & - \\
\hline $\mathrm{Cu}(\mathrm{mg} / \mathrm{l})$ & -0.1940 .173 & $0.281-0.287$ & $0.26-0.28$ & $0.162-0.207$ & $0.25-0.26$ & $0.188-0.195$ & $0.159-0.166$ & $0.13-0.18$ & $0.281-0.338$ & 40 \\
\hline $\mathrm{Cd}(\mathrm{mg} / \mathrm{l})$ & $0.0125-0.0129$ & $0.0128-0.013$ & $0.013-0.014$ & $0.0124-0.0129$ & $0.0125-0.0129$ & $0.0125-0.135$ & $0.0128-0.013$ & $0.013-0.0133$ & $0.0143-0.015$ & 0.2 \\
\hline $\mathrm{Ni}(\mathrm{mg} / \mathrm{l})$ & $0.031-0.034$ & $0.067-0.076$ & $0.047-0.048$ & $0.03-0.047$ & $0.029-0.035$ & $0.06-0.111$ & $0.027-0.029$ & $0.022-0.028$ & $0.027-0.137$ & 1.5 \\
\hline $\mathrm{Pb}(\mathrm{mg} / \mathrm{l})$ & $0.352-0.386$ & $0.382-0.386$ & $0.371-0.399$ & $0.27-0.37$ & $0.37-0.38$ & $0.216-0.288$ & $0.301-0.329$ & $0.287-0.384$ & $0.203-0.418$ & 5 \\
\hline $\mathrm{Cr}(\mathrm{mg} / \mathrm{l})$ & $0.131-0.143$ & $0.177-0.188$ & $0.136-0.137$ & $0.119-0.144$ & $0.152-0.166$ & $0.214-0.267$ & $0.104-0.115$ & $0.118-0.139$ & $0.112-0.313$ & 5 \\
\hline
\end{tabular}

The effect of the Experimental sites on the contents of micro and toxic elements in the wells irrigation water:

The analysis of variance data in Table (7) showed significant differences $(\mathrm{P} \leq 0.01)$ between the three different water sites in Rabigh Governorate with respect to their content of the studied micro and toxic elements ( $\mathrm{Zn}, \mathrm{Cu}, \mathrm{Pb}, \mathrm{Ni}, \mathrm{Cr})$. There were no significant differences between sites for the contents of cadmium, manganese and iron $(\mathrm{Cd}, \mathrm{Mn}, \mathrm{Fe})$. Data of means of micro and toxic elements content in water in the three sites (Table 8) indicate that Rabigh water contained the highest concentrations of $\mathrm{Fe}, \mathrm{Zn}, \mathrm{Mn}, \mathrm{Cu}$ and $\mathrm{Pb}$ at an averages of 5,150 and $0.408,0,095,0,143,0.371 \mathrm{mg} / \mathrm{L}$ ) compared to the water content of both Masturah and Kiliya villages. The highest water content of nickel and chromium (Cr) was in Masturah site well water $(0,075$ and $0,260 \mathrm{mg} /$ $\mathrm{L}$, respectively).

\section{TABLE (7): - ANALYSIS OF VARIABILITY OF MICRO AND TOXIC ELEMENTS OF WELLS WATER IN THE THREE SITES OF RABIGH GOVERNORATE}

\begin{tabular}{|c|c|c|c|c|c|c|c|c|c|}
\hline $\begin{array}{c}\text { Source of } \\
\text { Variation. }\end{array}$ & $\mathbf{d}$ & \multicolumn{4}{|c|}{ Micro-elements (mg/l) } & \multicolumn{4}{c|}{ Toxic elements (mg/l) } \\
\cline { 3 - 11 } & & $\mathbf{F e}$ & $\mathbf{Z n}$ & $\mathbf{M n}$ & $\mathbf{C u}$ & $\mathbf{C d}$ & $\mathbf{N i}$ & $\mathbf{P b}$ & $\mathbf{C r}$ \\
\hline Rep & 2 & 6.41 & 0.003 & 0.0004 & 0.0004 & 5.037 & 0.00038 & 0.0003 & 0.005 \\
\hline Loc & 2 & $\begin{array}{c}17.71 \\
\mathrm{Ns}\end{array}$ & $0.102^{* *}$ & $0.0022 \mathrm{Ns}$ & $0.0032^{* *}$ & $2.8 \mathrm{e} 7 \mathrm{Ns}$ & $0.00292 *$ & $0.0636^{* *}$ & $0.017^{*}$ \\
\hline Error & 4 & 5.01 & 0.001 & 0.0003 & 0.0001 & 2.28 & 0.0001 & 0.0003 & 0.002 \\
\hline
\end{tabular}

Showing a significant effect at $0.05 *$ Showing a significant effect at $0.01 * *$

Not significant for a significant level of $0.05 \mathrm{NS}$ 
TABLE (8): AVERAGE CONCENTRATIONS OF MICRO AND TOXIC ELEMENTS IN WELL WATER OF THE THREE SITES OF RABIGH GOVERNORATE COMPARED TO THE STANDARDS OF THE MINISTRY OF ENVIRONMENT, WATER AND AGRICULTURE (MEWA 2018) AND FAO (1985)

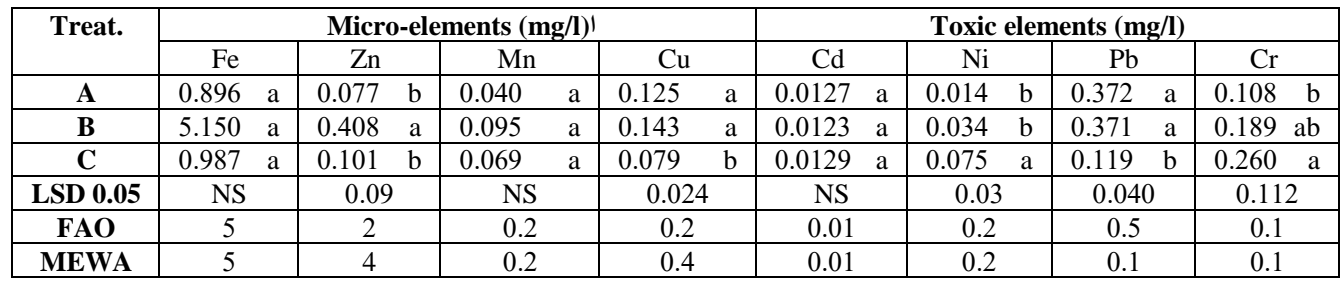

The averages followed by the same letters did not differ significantly from each other according to the Lsd test at a significant level of $0.05 *$

\section{Effect of experimental sites on soil content of micro and toxic elements}

The data for analysis of variance in table (9) indicate that there are high significant differences $(\mathrm{P} \leq 0.01)$ between the sites in the three different regions of Rabigh Governorate with respect to their soil composition of the studied micro and toxic elements ( $\mathrm{Zn}, \mathrm{Cu}, \mathrm{Pb}, \mathrm{Ni}, \mathrm{Cr} \mathrm{Cd}, \mathrm{Mn}, \mathrm{Fe}$ ), ). The data of averages of soil content of micro and toxic elements in the three sites (Table 10) indicate that the soil of the Kiliya villages area has the highest concentrations of micro and toxic elements of ( $\mathrm{Fe}, \mathrm{Zn}, \mathrm{Mn}, \mathrm{Cu}, \mathrm{Cd}, \mathrm{Ni}, \mathrm{Ph}, \mathrm{Cr}$ ) with means of $(271,2,1.47,10,67,1,17,0.023,1.55,4.92,2.09$ $\mathrm{mg} / \mathrm{L}$ ) compared to the soil content of the second site (Rabigh) and the third site (Masturah). There are no significant differences between the cities of Rabigh and Masturah in terms of soil content of manganese $(\mathrm{Mn}), \mathrm{Cu}$, cadmium $(\mathrm{Cd}), \mathrm{Ni}, \mathrm{Pb}$ and chromium $(\mathrm{Cr})$. The concentrations of iron $(\mathrm{Fe})$ and $\mathrm{Zn}(\mathrm{Zn})$ were higher in the soil of the area of the city of Masturah compared to the soil of the city of Rabigh.

\section{TABLE (9): - ANALYSIS OF VARIABILITY OF MICRO AND TOXIC ELEMENTS IN SOILS OF THE THREE SITES OF RABIGH GOVERNORATE}

\begin{tabular}{|r|c|c|c|c|c|c|c|c|c|}
\hline Source of & df & \multicolumn{4}{|c|}{ Micro-elements (mg/l) } & \multicolumn{4}{c|}{ Toxic elements (mg/l) } \\
\cline { 2 - 11 } Variation. & & $\mathrm{Fe}$ & $\mathrm{Zn}$ & $\mathrm{Mn}$ & $\mathrm{Cu}$ & $\mathrm{Cd}$ & $\mathrm{Ni}$ & $\mathrm{Pb}$ & $\mathrm{Cr}$ \\
\hline $\mathrm{Rep}$ & 2 & 122.5 & 0.006 & 0.62 & 0.007 & 0.0000007 & 0.01 & 0.0008 & 0.018 \\
\hline Loc & 2 & $* *$ & $* *$ & $* *$ & $* *$ & $* *$ & $* *$ & $* *$ & $2.382^{* *}$ \\
& & 12296.2 & 0.474 & 37.07 & 0.400 & 0.0000431 & 1.73 & 0.0598 & \\
\hline Error & 4 & 75.78 & 0.008 & 0.857 & 0.007 & 0.000002 & 0.016 & 0.001 & 0.02 \\
\hline
\end{tabular}

Showing a significant effect at $0.05 *$ Showing a significant effect at $0.01 * *$

Not significant for a significant level of 0.05 NS

TABLE (10): AVERAGE CONCENTRATIONS OF MICRO AND TOXIC ELEMENTS IN WELL WATER OF THE THREE SITES OF RABIGH GOVERNORATE COMPARED TO THE STANDARDS OF EUROPEAN UNION (2002):

\begin{tabular}{|c|c|c|c|c|c|c|c|c|c|c|}
\hline \multirow[t]{2}{*}{ Treat. } & \multicolumn{4}{|c|}{ Micro-elements (mg/l)! } & \multicolumn{6}{|c|}{ Toxic elements (mg/l) } \\
\hline & $\mathbf{F e}$ & $\mathbf{Z n}$ & Mn & $\mathbf{C u}$ & Cd & $\mathrm{Ni}$ & & $\mathbf{P b}$ & & $\mathrm{Cr}$ \\
\hline $\mathrm{A}$ & 271.2 & $1.47 \quad \mathrm{a}$ & $10.67 \mathrm{a}$ & $1.17 \quad \mathrm{a}$ & 0.023 & 1.55 & $\mathrm{a}$ & 0.492 & $\mathrm{a}$ & 2.09 \\
\hline $\mathrm{B}$ & 148.6 & 0.68 & $3.99 \mathrm{~b}$ & $0.47 \quad b$ & 0.016 & 0.24 & $\mathrm{~b}$ & 0.427 & $\mathrm{~b}$ & 0.54 \\
\hline $\mathrm{C}$ & 177.9 & 1.13 & $5.45 \mathrm{~b}$ & $0.64 \mathrm{~b}$ & $0.018 \quad \mathrm{~b}$ & 0.23 & $\mathrm{~b}$ & 0.221 & & 0.56 \\
\hline Lsd & 19.73 & 0.20 & 2.09 & 0.20 & 0.003 & 0.29 & & 0.07 & & 0.37 \\
\hline EU.(2002)(mg/kg) & - & 300 & - & 140 & 3 & 75 & & 300 & & 150 \\
\hline
\end{tabular}

The averages followed by the same letters did not differ significantly from each other according to the Lsd test at a significant level of $0.05 *$

\section{DISCUSSION}

Heavy metals means any chemical element with relatively high density or toxicity at low concentrations. The danger is that if it enters the body does not go out and accumulate over time, unlike other chemicals. The results of the study showed a significant variation between the plants developing in those sites with regard to their contents of micro and toxic elements. As noted by France et.al. (2010), differences between plant species were found to be significant in relation to heavy metal deposits within their tissues. A. tortilis plant, which grows in the village of Kiliya (the first site), has the highest concentrations of micro and toxic elements, especially $\mathrm{Fe}, \mathrm{Mn}, \mathrm{Cr}, \mathrm{Zn}$ together with the city of Rabigh, while the plants at the third location (the city of Masturah) 
had the lowest concentrations of these micro and toxic elements, except in the case of lead element $(\mathrm{Pb})$, in which it dominated villages of Kiliya and Rabigh city. This indicates that, the villages of Kiliya and Rabigh industrial city have a greater environmental pollution compared to the city of Masturah site, which is considered a clean city without industries and the plants growing in it are containing the lowest micro and toxic elements compared to Rabigh and Kiliya villages sites. The highest concentrations of these micro and toxic elements in A. tortilis shrubs compared to the other two sites is because Kiliya villages site soil contains the highest concentrations of these elements compared with the other two sites. Kiliya villages site is in the north and subjected to the northern eastern winds that carry micro metals. And from the previous studies Al-Farraj et al. (2007), studied concentrations of micro and toxic elements in A. tortilis at two sites in Saudi Arabia at the site of the gold cradle and away from it. They found high concentrations of $\mathrm{Cu}, \mathrm{Zn}, \mathrm{Pb}$, and $\mathrm{Cd}(0.4,2.4,61.5,21.3 \mathrm{mg}$ $/ 1$ respectively) at the gold cradle position and $0,15,2,04$, 0.25 , and $2.05 \mathrm{mg} / \mathrm{L}$ respectively at the remote site. In addition, in comparing micro and toxic elements contents of the plant Chloris gayana (kunth) (Rhodes), which grows in both Rabigh and Masturah sites, Rhods plants that grow in Rabigh contain higher concentrations of $\mathrm{Fe}, \mathrm{Zn}, \mathrm{Mn}, \mathrm{Cu}, \mathrm{Ni}$, $\mathrm{Pb}, \mathrm{Cr}$ ) than those growing in Masturah city, suggesting that these plants are exposed to a higher pollution rate because Rabigh is an industrialized city and Masturah is a city with no factories. The results of these tests indicate that the plants that grow at Rabigh city contain the highest rates of micro and toxic elements compared to those plants growing in the city of Mastura and Kiliya villages and their contents of these elements were lower. This is because the smoke and dust of factories in Rabigh city are airborne and are placed on the leaves of growing plants near the city and are absorbed into the plant, as well as through the roots that absorb these elements falling on the soil. In general, it can not be said that these plants are accumulater plants for micro and toxic elements because their contents are less than international and local standards. El-Nakhlawy et al., (2015) studied the effect of three industrial activities on concentrations of toxic metals $(\mathrm{Pb}, \mathrm{Ni}, \mathrm{Cr}, \mathrm{Cd})$ and micro elements ( $\mathrm{Fe}, \mathrm{Cu}, \mathrm{Zn}$ and $\mathrm{Mn}$ ) in Azadirachta indica leaves and found that the highest concentrations of $\mathrm{Pb}, \mathrm{Ni}, \mathrm{Cr}, \mathrm{Cd}$, $\mathrm{Fe}, \mathrm{Cu}, \mathrm{Zn}, \mathrm{Mn}$, were in the tree leaves located near the areas of paint factories, chemical and paper industries and in the areas of mineralization, plastic and building materials compared to the trees growing away from these sites. The most concentrated elements in the studied plants in the three sites are $\mathrm{Fe}, \mathrm{Pb}, \mathrm{Zn}, \mathrm{Mn}$. These results are in line with the findings of Osma et al. (2012) who studied the content of micro elements in plants in 15 sites in Turkey and found it is always topped by $\mathrm{Fe}, \mathrm{Pb}, \mathrm{Zn}$ and $\mathrm{Mn}$ elements. Kuriakose, et al., (2008); Wei, and Zhau, (2008) reported that most of the sources of contamination of plants by micro-elements are non-ferrous metal smelting, battery industry, iron and steel industry, cadmium production, waste incineration, Cities, traffic congestion. According to Nagajyoti et al., 2010, the toxicity of heavy metals in plants varies according to the plant and its age, as well as the properties of the metal, chemical concentration and composition. There are significant differences between plants in their ability to accumulate heavy and toxic elements within their tissues. The plants absorb heavy and poisonous elements not only by leaves but also by roots. The roots absorb these elements if the soil is exposed to pollution by any of the different pollution methods, including the accumulation of these elements after their transport by air from the surrounding factories and industries Minerals, and mines, or through the tainted fog of oceans, acid rain, etc. (Brooks, 1998, Zhao, et al., 2000, and Whiting et al., 2002, and McGrath et al., 2002) and from roots elements move to stem then to leaves.

\section{Micro and toxic elements in the irrigation water of wells in Rabigh Governorate:}

The micro and toxic elements contents of the wells water used for irrigation varied in the three regions. That the water of Rabigh contained the highest concentrations of iron $(\mathrm{Fe})$, zinc $(\mathrm{Zn})$, manganese $(\mathrm{Mn})$, copper $(\mathrm{Cu})$ and lead $(\mathrm{Pb})$ compared to the content of water of both Masturah city and Kiliya villages. The highest water content of nickel(Ni) and chromium $(\mathrm{Cr})$ was in Masturah water $(0,075$ and $0,260 \mathrm{mg}$ / $\mathrm{L}$ respectively) and the highest metal content of water of the villages of Kiliya site was $\mathrm{Pb}$, shared with Rabigh. All elements concentrations in these three sites well water were below the standards of the World Food and Agriculture Organization (FAO,1985) and the Ministry of Water and Agriculture (MEWA,2005) of Saudi Arabia except Fe in the water of Rabigh wells, $\mathrm{Cd}$ and $\mathrm{Cr}$ in the wells water at all sites. The increase in micro and toxic elements in well water of the city of Rabigh compared to the content of these elements in wells water of of Masturah city is because the city of Rabigh is an industrial city with various industries as well as densely populated and traffic density is high compared to the city of Masturah and Kiliya, and the sewage from the factories as well as domestic wastewater of this city permeates and seeps into the soil around the city and dips and reaches the groundwater which is the source of this water. In a similar study carried out by Oyekul and Eludoyin (2010) in urban areas of Nigeria, it was found that their groundwater contains high levels of micro and toxic elements, especially $\mathrm{Fe} \mathrm{Cu}, \mathrm{Pb}, \mathrm{Co}$ ) above WHO standards although this groundwater is $2 \mathrm{~km}$ from the landfill. The results of this study differ from those found by (Zaki, 2012) who found that most well water contaminated with micro and toxic elements ( $\mathrm{Fe}, \mathrm{Cu}, \mathrm{Zu}, \mathrm{AL}, \mathrm{Mn}, \mathrm{Ba} \mathrm{Ni}, \mathrm{Pl}, \mathrm{Cd}, \mathrm{Cr}$, $\mathrm{AG}, \mathrm{Mo}, \mathrm{Co}, \mathrm{Be}, \mathrm{V}, \mathrm{Av}, \mathrm{Sb}, \mathrm{Ti}, \mathrm{U})$ are the wells of the Masturah area followed by Rabigh region, then the wells water of Kiliya region, and therefore not suitable for drinking or use for agricultural purposes, but all these wells are located in valleys flowing in the waters of the Red Sea in the western region of the Kingdom, and these valleys may also carry sewage water. The results showed that salinity of well water used in irrigation in these three sites is below the standard of FAO (1985), but less than the standard set by Saudi Ministry of Environment, Water and Agriculture (MEWA, 2005). According to these results the well waters in the three sites can safely be used for irrigation. 


\section{Micro and toxic elements in soil in Rabigh Governorate:}

The results of the soil content of micro and toxic elements in the three sites indicate that the soil of the villages of Kiliya (site A) contained the highest concentrations of Fe, Zn, Mn, $\mathrm{Cu}, \mathrm{Cd}, \mathrm{Ni}, \mathrm{Pb}$ and $\mathrm{Cr}$ compared to the soil content of both the second site (Rabigh) and the third site (Mastourah). There are no significant differences between the cities of Rabigh and Masturah in terms of soil content of $\mathrm{Mn}, \mathrm{Cu}, \mathrm{Cd}$, $\mathrm{Ni}, \mathrm{Pb}$ and $\mathrm{Cr}$. The concentration of iron $(\mathrm{Fe})$ and zinc $(\mathrm{Zn})$ was higher in the soil of the site of the city of Masturah compared to the soil of the city of Rabigh. The villages of Kiliya site is located in the north of Masturah and Rabigh, which is often exposed to the northern winds. It is not excluded that air is an important source of soil pollution from micro- and toxic elements as is indicated by (Khan et al., 2008; Zhang et al., 2010). Nagajyoti et al. (2010) and Ross (1994) pointed out that whenever the season is hot, weathering, rock decomposition, and windy seasons such as summer are intensively dusty and windy. Heavy dust, which comes from desert areas contains high levels of iron and lower amounts of manganese, zinc, chromium, nickel, and lead.

\section{CONCLUSION}

The results of this study showed significant differences between the three sites of Rabigh governorate, Kiliya villages (first site), Rabigh city (second site) and the location of the city of Masturah (the third location) with regard to the content of micro and toxic elements in their plants, the water used in irrigation and in their soils. The concentrations of all these traits in plants, water and soil in all sites are below the standards set by FAO(1985) and (MEWA, 2005) except for electrical conductivity (EC) in water was higher than FAO and MEWA, and chromium was higher than that of FAO and MEWA. The natural plants and wells water used for irrigation in the vicinity of Rabigh city are characterized by the highiest concentrations of the micro and toxic elements compared to the site of the city of Masturah and the villages of Kiliya site. The city of Masturah site came second and then the villages of Kiliya site is characterized by the lowest concentrations. The soil of the villages of Kiliya site is characterized by the highest content of micro elements (Fe, $\mathrm{Zn}, \mathrm{Mn}, \mathrm{Cu}$, Cadmium, $\mathrm{Ni}, \mathrm{Pb}$ and $\mathrm{Cr}$ ) with averages (271,2, 1.47) , 10,67,17,0,223, 1,55, 4,92, 2,09 mg / L) compared with the soil content of both the second site (Rabigh) and the third site (Masturah). $\mathrm{pH}$ value is between 7 and 8 in all the water or soil, which means that water of wells used in irrigation and soil in the sites of Rabigh province is a base and not acidic, but its base is light The location of Rabigh city is considered the most polluted compared to the sites of Masturah and the villages of Kiliya. This pollution has not reached a dangerous stage because its standards are below the standards set by international and local standards.

\section{REFERENCES}

[1] R. Aloni, E. Aloni, M. Langhans, C.I. Ullrich. "Role of Cytokinin and Auxin in Shaping Root Architecture: Regulating Vascular Differentiation, Lateral Root Initiation, Root Apical Dominance and Root Gravitropism". Annal of Botany, vol. 97, issu. 5: 883893. 2006.

[2] A.S. AL-Farraj, M.I. Al-Wabel. "Heavy Metals Accumulation of Some Plant Species Grown on Mining Area at Mahad AD'Dahab",
Saudi Arabia. Journal of Applied Sciences, Volume 7 (8): 1170 1175. 2007.

[3] F. Alghabari, M. Z .Ihsan, S. Hussain, G. Aishia, I. Daur ." Effect of Rht alleles on wheat grain yield and quality under high temperature and drought stress during booting and anthesis". Environmental Science and Pollution Research, 1-10.2015.

[4] American Public Health Association (APHA ). Standard methods for examination of water and sewage water , 20 .Th., Ed. , APHA , Washington, D. C. 1998

[5] M. Arianoutsou, P. W Rundel, W. L. Berry. "Serpentine endemics as biological indicators of soil elemental concentrations". In B. Markert (Ed.), Plants as biomonitors. Indicators for heavy metals in terrestrial environment. Weinheim: VCH.1993.

[6] C. I. Brandt, R. W. Rhoades. "Effects of limestone dust accumulation on composition of forest community". Environmental Pollution, 3, 217-225. 1973.

[7] R. R. Brooks. (Ed0 Plants that Hyperaccumulate Heavy Metals. CAB International, Oxon, UK, 356 pp. 1998.

[8] A.T. Czaja. "Die wirkung von verstaubtem kalk und zement auf pflanzen. Qualitas Plantarum et Materiae Vegetabiles", 7, 184212. doi:10.1007/BF01099766. 1960.

[9] A.T. Czaja. "Zementstaubwirkungen auf pflanzen: Die entstehung der zementkrusten". Qualitas Plantarum et Materiae Vegetabiles, 8, 201 -238. doi:10.1007/ BF01226257. 1961.

[10] A. T.Czaja. "Uber das problem der zementstaubwirkungen auf pflanzen. Staub", 22, 228-232. 1962.

[11] F.S. El-Nakhlawy, M. Shaheen, F. Almehmadi, A. Al-Shareef (2015). Heavy Metals Contents in Ziziphus Tree Leaves Under the Effect of Different Industrial Activities. Journal of Agricultural Science. 6 (1) : 110-115.

[12] F.S. El-Nakhlawy, M. Shaheen, F. Almehmadi, M. Ishan A. AlShareef."Assessment of seasonal variation for air pollutant". 2016.

[13] FAO / WHO. Joint FAO/WHO Food Standers Program , Codex Alimentarius Commission. CAC / Vol. XVll.FAO. Roma and WHO, Geneva. 1985

[14] FAO/WHO . Joint FAO/WHO Food Standards Programme, FAO, Rome. C. M ..... Amended in 1966, 1969, 1993, 1995 and 2007) $f$. Definitions . 2007

[15] R Guderian, “Terrestrial ecosystems: particulate deposition”. In A H. Legge \& S. V. Krupa (Eds.), Air pollutants and their effects on the terrestrial ecosystemAdvances in environmental science and technology, vol 18 (pp. 339-363). New York, NY: Wiley. 1986.

[16] C. Hemlata. " Effect of cement dust on growth performance of Trigonellafoenum graecum, and the reversal of its inhibitory effect by different substance and growth rehalators". Acta Ecologica, 13(2), 103-108. 1991.

[17] C. Hong-Xia, J. Gao-Ming, N. Shu-Li, J. Chuang-Dao, L. MeiZhen, , Y. Shun-Li. Ecophysiological response of plants to combined pollution from heavy-duty vehicles and industrial emissions in higher humidity. Journal of Integrative Plant Biology, 48(12), 1391-1400. 2006.

[18] S. Khan, Q. Cao,Y. Zheng, Y. Huang, Y. Zhu.” Health risks of heavy metals in contaminated soilsand food cropsirrigated with wastewater in Beijing China". Environ. Pollut. , 152(3):686-692. 2008.

[19] S.V. Kuriakose, M.N.V. Prasad. "Cadmium as an environmental contaminant: Consequences to plant and human health". In Trace Elements as Contaminants and Nutrients: Consequences in Ecosystems and Human Health, Prasad, M.N.V., Ed. John Wiley \& Sons: New York, pp. 373-412. 2008

[20] H. Lepedus, V. Cesar, M. Suver. "The anual changes of chloroplast pigments content in currenr- and previousyear needles of Norway spruce (Picea abies L. Karst.) exposed to cement dust pollution". Acta Botanica Croatica, 62(1), 27-35. 2003.

[21] M. Mandre, L. Tuulmets. "Pigment changes in norway spruce induced by dust pollution. Water, Air, and Soil Pollution", 94(34), 247-258. 1997.

[22] M. Mandre, R. Kask, J. Pikk, K. Ots. "Assessment of growth and stemwood quality of Scots pine on territory influenced by alkaline industrial dust". Environmental Monitoring and Assessment, 138(1-3), 51-63. 2008.

[23] S.P. McGrath, F.J. Zhao, E. Lombi. "Phytoremediation of metals, metalloids, and radionuclides". Adv. Agronomy 75: 1-56. 2002.

[24] MEWA (Ministry of Environment, water and Electricity). "National wastewater Regulations, Section III - 2.and 3.2.3 
Riyadh, Saudi Arabia", optimization approach. Water Resour Manage 21:1207-1224. 2005.

[25] K. Nagajyoti, Lee, D. T.V.M. Streekanth. "Heavy metals; occurrence and toxicity for plants"; a review. Environ chem. Lett. $8: 199-216.2010$

[26] E. Osma, M. Serin, Z. Leblebici, A. Aksoy. "Heavy metals accumulation in some vegetables and soils in Istanbul". Ekoloji, 21 (82): 1-8. 2012

[27] Oyekul, L. and Eludoyin, H. (2010). Heavy metal contamination of ground water resources in Nigeria urban settlement. Afr. J. Environ. Sci. Technol. 4(4): 201-212.

[28] D. J. Roser, D. R. Melick, R.D. Seppelt. "Reductions in the polyhydric alcohol content of lichens as an indicator of environmental pollution". Antarctic Science, 4, 185-188. 1992.

[29] S.M. Ross. "Toxic Metals in Soil - Plant Systems". Wiley, Chichester, P. 469. 1994.

[30] M. Santelmann, E. Gorham. "The influence of airborne road dust on the chemistry of Sphagnum mosses". Journal of Ecology, 76, 1219-1231. 1988
[31] SAS, (2010). SAS Institute Inc ., Cary Nc ., USA( Soft Ware Statistical Program)

[32] W. R. Shelton, J. Harper. "A rapid method for determination of total phosphorus in soil plant material". Journal of Science 15: 403 413. 1941

[33] S. Wei, Q. Zhou. "Trace elements in agro-ecosystems. In Trace Elements as Contaminants and Nutrients: Consequences in Ecosystems and Human Health, Prasad", M.N.V., Eds. John Wiley \& Sons, Inc: New York, pp. 55-80. 2008

[34] S.N. Whiting, R. D. Reeves, A. J. M. Baker. Mining, metallophytes and land reclamation. Mining Environmental Management. 11: 12 16. 2002.

[35] F.J. Zhao, E. Lombi, T. Breedon, S.P. McGrath. Zinc hyperaccumulation and cellular distribution in Arabidopsis halleri. Plant Cell Environ. 23: 507-514. 2000.

[36] M. Zaki. "Evaluation of the physico-chemical properties and quality of Qinuna dam water". This thesis is submitted for the folfilment of the requirements for a master's degree in environmental science, University of Rabigh. 2019. 